\title{
Oil and Women: A Re-examination
}

\author{
ASTGHIK MAVISAKALYAN†* and YASHAR TARVERDI†** \\ + Bankwest Curtin Economics Centre, Curtin Business School, Curtin University, Australia.
}

ABSTRACT: In a seminal article, Ross (2008) reports a negative correlation between oil production and women's representation in the labour force and politics across countries. This article re-examines these relationships exploiting variations in oil endowments to address endogeneity concerns. We confirm that oil production causes decline in women's representation. Additionally we show that, consistent with Dutch disease effects, oil production decreases women's employment in the traded sector. However, it also leads to an increase in women's employment in the nontraded sector. We explore some social consequences of oil production and show that it results in women marrying earlier and having more children.

JEL classification: J16; J21; O13.

Keywords: natural resources; female employment.

*Postal address: GPO Box U1987, Perth WA 6845, Australia. E-mail: astghik.mavisakalyan@curtin.edu.au.

** Postal address: GPO Box U1987, Perth WA 6845, Australia. E-mail: yashar.tarverdi@curtin.edu.au. 


\section{INTRODUCTION}

In a highly influential article published in American Political Science Review, Michael Ross (2008) reports evidence that calls into question the widely-held view that gender inequalities observed in the Middle East are due to the region's Islamic traditions (e.g. Sharabi, 1992; Inglehart and Norris, 2003). He suggests that 'oil not Islam, is at fault' (p. 107). Ross (2008) argues that oil production may exacerbate gender inequalities in the labour market when these are gender-segregated and there are Dutch disease effects. Consistent with this theory, he demonstrates, in a large sample of countries, a significant negative relationship between oil production and women's representation in the labour force and politics.

Ross's article is significant for a number of reasons. Reliance on natural resources is prevalent in many developed and developing economies. However, it is an open question whether the extractive sector can generate sustainable development (see e.g. van der Ploeg, 2011 for a review). The literature on resource wealth and development demonstrates that resource-rich countries in fact tend to grow more slowly than their resource-poor counterparts - a phenomenon coined the resource curse (e.g., Sachs and Warner, 1999, 2001). However, the distribution of gains and losses from resource wealth is central to whether or not it promotes development and growth (e.g., Mehlum et al., 2006). The findings by Ross (2008) have potentially important implications for central controversies in this literature.

Gender inequalities are at the core of the debate about socio-economic development (e.g., Duflo, 2012; Bandiera and Natraj, 2013). Not only are such inequalities intrinsically problematic, they seem to hamper development (e.g., Klasen and Lamanna, 2009; Cavalcanti and Tavares, 2016). Equal distribution of gains from natural resources has been identified as a central goal in achieving gender equality and women's empowerment in the new Sustainable Development Goals (SDGs) adopted by world leaders at the 2015 UN summit. Yet gender dimensions of the extractive sector remain some of the least understood aspects of the literature on economic effects of resource wealth (Ross, 2015). The findings by Ross (2008) present a pioneering and significant contribution to the knowledge base that may inform such initiatives.

Unsurprisingly, Ross (2008) has received significant prominence. The study won the 2009 Heinz Eulau Prize for the best article published in the American Political Science Review. It has informed a large body of research in a range of social sciences including various subfields of economics such as demographic economics (e.g., Bertoli and Marchetta, 2015; Do et al., 2016), labour economics (e.g., Gaddis and Klasen, 2014; Burke and Dundas, 2015), development economics (e.g., Orihuela, 2013; Fenske, 2015), economic history (e.g., Alesina 
et al., 2013; Hansen et al., 2015), energy and resource economics (e.g., Wick and Bulte, 2009; Parcero and Papyrakis, 2016) and political economy (e.g., de Soysa and Vadlamannati, 2011; Wehner and de Renzio, 2013), among others.

Nevertheless, there has been significant critical engagement with Ross's findings including various analytical discussions (Caraway, 2009; Charrad, 2009; Norris, 2009) or attempts at empirical re-examinations (Kang, 2009; Groh and Rothschild, 2012; Rørbæk, 2016). These attempts have involved useful variations such as introducing additional control variables or considering sample sensitivities. Some have confirmed the relationship between oil and women's representation (Kang, 2009), while others have shown it is less robust raising concerns over causality of the effect documented by Ross (2008) (Groh and Rothschild, 2012). ${ }^{1}$ Often, however, the choice of empirical specifications in these exercises is questionable due to issues of bad controls, multicollinearity and lack of theoretical guidance (Ross, 2009, 2012).

We follow these studies in undertaking a re-examination of oil and women's representation. Our empirical design closely follows Ross (2008): we study the same period (19932002), using a similar or, where possible, identical sample of countries and do not alter his list of controls or their definitions in the baseline models (although we do check the sensitivity of the results to key additional controls). Instead, we consider robustness tests and extensions along four important dimensions.

First, we study the robustness of the results in Ross (2008) to a number of alternative definitions of oil wealth in addition to oil rents per capita measure used in the study. Many different definitions of resource wealth have been used in the literature including the rents generated by production, the value of exports and reserves, expressed in various ways. As Ross himself suggests in a different study, this has made it easy to 'shop among alternative measures to generate a given outcome'. (Ross, 2015, p. 241). We demonstrate that the results in Ross (2008) are largely robust to using alternative measures of oil wealth. However, we show that the method used to normailise these values matters: the measures of oil wealth, when expressed as a fraction of GDP rather than on a per capita basis, are no longer statistically significantly correlated with measures of female representation.

Second, we raise a similar concern as Groh and Rothschild (2012): whether the relationship Ross (2008) documents is causal. ${ }^{2}$ Economies that are different for a variety of unobserved reasons may differ both in their oil production and in their representation of women.

\footnotetext{
${ }^{1}$ Some of these studies have also attempted to challenge the finding on the lack of significance of Islam in explaining women's representation in Ross (2008) (e.g., Norris, 2009; Groh and Rothschild, 2012). The focus of our study is rather to assess the validity of the significant relationship established by Ross (2008): that between oil and female representation.

2 It should be noted that Ross (2008) himself is rather careful in attaching causal interpretation to the results.
} 
The way we approach the task of exploring this issue, however, is different from Groh and Rothschild (2012) who simply control for additional variables in an attempt to mitigate the problem of unobserved heterogeneity. We acknowledge that unobserved heterogeneity can not be fully and adequately accounted for. To identify the causal effect of oil production on women's representation we re-estimate Ross's model exploiting differences in oil endowments as an instrument (for similar identification approaches in other contexts see e.g. Tsui, 2011; Cotet and Tsui, 2013a,b). We show that the effects estimated by Ross (2008) are causal: our two-stage least squares (2SLS) estimates of the effect of oil production on women's representation in labour force and politics are negative and significant.

Third, we study alternative measures of female representation as a dependent variable. In Ross's study, female labour force participation is the key outcome of interest. Ross hypothesizes, without providing empirical evidence, that declining demand for female labour caused by the crowding out of the traded sector due to Dutch disease effects, may be a mechanism responsible for the overall negative relationship between oil production and female labour force participation he documents. ${ }^{3}$ We provide an empirical test for this hypothesis, and show that oil production indeed leads to a decrease in the share of women employed in the industry sector. However, Ross's framework does not allow for the possibility that women may shift to services sector (his baseline model assumes that women cannot join the nontraded sector). We challenge this assumption and show that oil production in fact causes an increase in women's employment in services. Our findings therefore suggest that oil is not only a curse for women and that with an expansion of the services sector the negative oil effect documented by Ross (2008) may be potentially reversed.

Finally, we study some social consequences of oil production for women. Ross (2008) argues that such consequences can be 'profound' (p.107) and that oil production can in particular have implications for the timing of parenthood and fertility. ${ }^{4}$ We test this proposition and demonstrate that oil production indeed results in women marrying earlier and having more children.

The remainder of this paper is structured as follows. The next section summarises Ross's study. Section 3 presents the results of our robustness tests and additional analyses. Section 4 concludes the paper.

\footnotetext{
${ }^{3} \mathrm{He}$ also suggests a second mechanism: declining supply of female labour caused by household income effects, i.e. higher male incomes and/or government transfers (Ross, 2008).

${ }^{4}$ Ross (2008) empirically explores the implications of oil production for gender inequalities in education however he does not explore other social effects.
} 


\section{ROSS'S STUDY}

Ross (2008) empirically tests two propositions. First, that oil production will reduce women's labour force participation; and second, that by doing so, it will also reduce women's political influence. The first proposition directly follows from introducing an assumption on the presence of gender-segregated labour markets in resource-based economies characterised by Dutch disease effects (e.g., Corden and Neary, 1982; Corden, 1984). If gender-based segregation in the labour market is such that women can only work in the traded sector, and men in the nontraded sector, the shift away from the traded sector to the nontraded sector due to Dutch disease will (i) reduce the demand for female labor and (ii) reduce the supply of female labour caused by household income effects: higher male wages and/or higher government transfers (Ross, 2008). The second proposition directly follows from the first one, assuming that female political influence is 'partly a function of female labor force participation' and is enhanced by it through various dynamics at an individual, social and economic levels (p. 110, Ross, 2008).

To explore these propositions, Ross (2008) analyses the relationships between measures of oil production, women's labour force participation and their political representation by taking two approaches to estimation. The first approach is based on a first-differences model with country fixed-effects, and employs pooled time-series cross-sectional data between 1960 and 2002 (Ross, 2008). The second approach, which guides most of the analysis in the paper, is based on a cross-country model with a between estimator and covers all countries in the period from 1993-2002 (averages of variables over this period are used).

Our re-assessment exercise is based on the later approach. The cross-country relationship between oil production and women's representation in labour force and politics of country $i$ is established by estimating variants of the following model using ordinary least squares (OLS):

$$
\bar{Y}_{i}=\alpha+\beta \bar{x}_{i}+\varepsilon_{i} \text { for all } i=1, \ldots, N
$$

where $x_{i}$ is a series of explanatory variables. All economic variables are measured in constant 2000 dollars. Furthermore, all of the variables are standardized 'to make comparisons easier' (p. 113, Ross, 2008). The variables come from standard sources such as the World Bank, Inter-Parliamentary Union, Polity IV database, and are detailed in the original paper. 
Our analysis is based on the dataset constructed by Michael Ross based on these sources and used in the paper. ${ }^{5}$

The analysis employs two dependent variables. The first one is female labor force participation: the female share of the formal labor force (Ross (2008) subtracts agricultural workers and foreign workers from this measure). The second one is women's political representation captured via two proxies: parliamentary seats held by women as a fraction of total seats in parliament, and ministerial seats held by women as a fraction of total ministerial seats.

The independent variable of interest, oil rents per capita, is measured as the total value of each country's annual oil and natural gas production minus extraction costs, divided by its mid-year population. Ross (2008) additionally includes a number of controls: (i) $\log$ of GDP per capita and its squared term; (ii) working age, the fraction of the population between the ages of 15 and 64; (iii) a Middle East dummy; (iv) Islam, a variable that measures the Muslim fraction of each country's population; (v) a Communist dummy (for states that had communist legal systems at some point since 1960). The models of women's political representation additionally control for (vi) a proportional representation dummy to denote states whose parliaments are chosen through proportional representation; (vii) a closed list dummy for electoral systems with closed lists; and (viii) Polity, a 21-point scale to measure a country's democracy level. This is precisely the list of baseline controls used in our analysis (not all models include all controls; our choices of specific sub-sets of these in various models are identical to those in Ross (2008)).

\section{RE-EXAMINATION}

Following the empirical design described in Section 2, Ross (2008) shows that oil production reduces women's representation in the labour force and politics. In what follows, we employ the same design to consider robustness tests and extensions along several dimensions.

Parsimonious specifications. We start with estimating various parsimonious versions of equation 1. By looking at the changes in the effects of the oil rents per capita between the parsimonious and baseline models, we are able to evaluate the degree of selection on observables. Moreover, this exercise enables us to test the sensitivity of the results to inclusion of potentially endogenous controls such as the working age population or GDP per capita. Table 1 presents the results.

\footnotetext{
${ }^{5}$ The dataset has been made available via Harvard Dataverse (Ross, 2010).
} 
The specification underlying the results presented in column (1) excludes the entire list of baseline controls. We confirm a significant and negative correlation between oil rents per capita and female labour force participation. Next, in the results reported in column (2), the Muslim fraction of countries' population is controlled for. This variable is negatively correlated with female labour force participation, however this relationship is not robust to including additional controls in subsequent models. The estimated coefficient on oil rents per capita, while negative, is smaller in magnitude. The results presented in column (3) suggest that being in the Middle East is negatively correlated with female labour force participation while the effect of Communist heritage is positive, although statistically insignificant in this particular specification. The nature of the relationship between oil rents per capita and female labour force participation is largely insensitive to the inclusion of these additional controls although coefficient on oil rents per capita is reduced further. We control for the share of a country's working age population in the results presented in column (4) while column (5) also includes income and income squared terms as controls. The share of the working age population is negatively correlated with female labour force participation while the significant estimates on income and income squared are consistent with cross-country evidence suggesting that female labor participation rate exhibits a U-shaped relation with economic development (e.g. Goldin, 1995; Tam, 2011). Inclusion of measures of working age population and income has surprisingly little effect on the estimated magnitude of the significant negative coefficient on oil rents per capita. ${ }^{6}$

Overall, the sensitivity of the coefficient on oil rents per capita to the inclusion of baseline regressors is suggestive of a certain degree of selection on observables. At the same time, there is a substantial increase in the values of R-squared from the parsimonious specifications to the baseline specification indicating that the inclusion of baseline regressors contributes to explaining variation in female labour force participation.

[Table 1 about here.]

Alternative measures of oil wealth. Several measures of oil wealth have been employed in the literature on resource wealth. What this means, according to Ross (2015), is that 'researchers have explored many potentially consequential dimensions of resource wealth, but it has also made it easy for them to shop among alternative measures to generate a given

\footnotetext{
${ }^{6}$ In an effort to address the endogeneity of GDP more directly, we followed Alexeev and Conrad (2009) to use exogenous geographical factors to estimate the countries' per capita GDP and used this estimated measure as a control variable in the regressions (including a squared term). This adjustment did not alter the estimated negative significant coefficient on oil rents per capita in the model with the full list of baseline controls. The results are available on request.
} 
outcome' (p.241). Some of the commonly employed measures of resource wealth in the literature, in addition to production measures, include the value of exports (e.g. Barro, 1999; Ross, 2001) and reserves (e.g. Laherrere, 2003; Tsui, 2011). In order to be sure that the results in Ross (2008) are not driven by the choice of his measure, we conduct analyses using alternative measures of oil wealth in the models of female labour force participation.

The results of this exercise are presented in Table 2. In column (1) we reproduce the baseline results with full set of controls in Ross (2008) using his oil rents per capita measure (corresponding to column (4) of Table 2 in the original paper). In columns (2) and (3) we use net oil exports and oil reserves measures - both in per capita terms - to proxy for oil wealth. ${ }^{7}$ The data for net oil exports comes from Ross and Mahdavi (2015) while oil reserves data is sourced from Tsui (2011). ${ }^{8}$ The results are robust to using these alternative measures of oil wealth in per capita terms - in all cases we establish a negative link between oil wealth and female labor force participation.

Next, we alter the method used to normalise the various measures of oil wealth. The results reported in columns (4)-(6) are based on using oil rents, net oil exports and oil reserves expressed as fractions of GDP rather than on a per capita basis. These measures reflect the true importance of oil in the economy potentially better than per capita measures (Sachs and Warner, 2001). However, they are also more likely to produce biased results since the importance of the resources in the economy may be caused by factors unrelated to natural resources (Alexeev and Conrad, 2009). In our context, the results with oil wealth measures expressed as a share of GDP no longer yield significant results. Consistent with this, the Rsquared values from models where GDP is used as the denominator for the measures of oil wealth are significantly smaller compared to those from models with per capita measures of oil wealth. We obtain similar estimates on other controls across all models.

[Table 2 about here.]

Addressing endogeneity of oil production. The analysis in Ross (2008) suggests that oil production is significantly correlated with female representation in labour force and politics, but it cannot tell us weather the relationship is causal. Studies have shown that female representation in labour force and politics can affect economic development (e.g., Klasen and Lamanna, 2009; Jayasuriya and Burke, 2013; Cavalcanti and Tavares, 2016); various strands of literature demonstrate that women's representation bears implications for decision-making

\footnotetext{
${ }^{7}$ Net oil exports are the difference of oil and gas exports and imports. Oil reserves are computed based on the past and new oil discoveries and depletion.

${ }^{8}$ The sample size differences across the models are due to missing data on these additional dependent variables.
} 
on various issues such as government expenditures (e.g., Chattopadhyay and Duflo, 2004; Mavisakalyan, 2014) or corporate governance (e.g., Adams and Ferreira, 2009; Capezio and Mavisakalyan, 2016). We therefore cannot completely rule out potential influences of women's representation over decisions about resource extraction. Perhaps more important than this reverse causality problem, economies that are different for a variety of reasons may differ both in their oil production and in their representation of women.

We take two approaches to mitigate the problem of endogeneity. First, we include additional variables that could be correlated with hitherto unexplained parts of female representation. Nevertheless, this approach cannot fully account for all confounding influences. Therefore we also employ an instrumental variable approach as our second and main strategy, to arrive at the estimates of the causal effect of oil production on female participation. The remainder of this sub-section presents the results of these analyses.

Robustness to additional controls. As a first step we include additional variables that could be potentially correlated with the unexplained parts of female labour force participation. We sequentially introduce these variables into the estimations of equation 1 . Table 3 presents the results. To allow for comparisons, column (1) reports the results with the full set of baseline controls in Ross (2008) (corresponding to column (4) of Table 2 in the original paper).

Human capital can have profound implications for various sectors of the economy, including the outcomes of the resources sector. On the other hand, it is possible that with higher human capital some of the barriers to female labor force participation may be less pronounced. For example, there is evidence to suggest that gender-discriminatory attitudes are less prevalent among more educated individuals (Mavisakalyan, 2015). In column (2), we control for the average years of schooling in the population over the age of 15 , sourced from World Bank (2016). The estimated coefficient on the average years of schooling, while positive, is statistically insignificant; its inclusion does not alter the estimated negative significant effect of oil rents per capita on female labour force participation. ${ }^{9}$

There is a voluminous literature on the relationships between institutions, natural resources and economic performance. Natural resources may deteriorate the quality of institutions, which, in turn may lower economic performance (e.g. Baland and Francois, 2000; Leite and Weidmann, 2002; Isham et al., 2005; Arezki and Bruckner, 2011; Sala-i Martin and Subramanian, 2013). Furthermore, the relationship between natural resources and economic

\footnotetext{
${ }^{9}$ We additionally explored the possibility that with higher human capital the effect of oil on female representation might weaken by including an interaction term of oil rents per capita and years of schooling as a control. Consistent with this possibility, the estimated coefficient on the interaction term was positive while that on oil rents per capita remained negative, however these estimates were not statistically significant (the results are available on request).
} 
performance may be conditional on the quality of institutions. For example, Mehlum et al. (2006) demonstrate that natural resources foster economic growth in places with good quality of institutions but inhibit growth in places where institutions are extortive and corrupt. ${ }^{10}$ At the same time, institutions are highly relevant for female representation across countries (Amin and Islam, 2015; Austen and Mavisakalyan, 2016) - a possibility that may introduce bias in our estimates of oil rents per capita if not adequately addressed. In column (3) we incorporate measures of countries' contemporary institutional quality and institutional heritage into the analysis. First, we control for governance - a composite measure of the set of traditions and institutions by which authority in a country is exercised - sourced from the Worldwide Governance Indicators (Kaufmann et al., 2010). ${ }^{11}$ Second, we include dummies for countries' legal origins (distinguishing between English, French, German and Scandinavian traditions); these have been linked with a broad range of economic outcomes of countries (La Porta et al., 2008). We estimate a highly significant positive coefficient on Governance. ${ }^{12}$ Controlling for these additional variables only marginally affects the size of the negative significant coefficient on oil rents per capita. ${ }^{13}$

In addition to formal institutions, we attempt to evaluate whether accounting for the disparities in the weight of the informal economy in different countries affects the results. Not only resource endowment may affect formal institutions, it may in some cases boost the activities of the informal economy (van der Ploeg, 2011). Our estimates on oil rents per capita will be biased, if women tend to work more in the informal sector. To address this issue directly, in column (4) we control for a measure of the size of informal economy as a share of GDP. Sourced from Schneider (2002), this measure is based on estimates in 100 countries in the year 2000. Including this variable leads to a significant drop in the sample size due to missing information for a number of countries. Nevertheless, we confirm the significant negative association between oil rents per capita and female labour force participation;

\footnotetext{
${ }^{10}$ See also Hodler (2006); Collier and Hoeffler (2009); Bhattacharyya and Hodler (2010) for similar ideas.

${ }^{11}$ This measure is constructed via Principle Components Analysis using the six dimensions of governance: voice and accountability, political stability and absence of violence, government effectiveness, regulatory quality, rule of law and control of corruption (see e.g. Tarverdi, 2016; Tarverdi and Rammohan, 2017). Using individual dimensions instead yields results similar to those reported here.

${ }^{12}$ Additionally, we estimated a model where an interaction term of oil rents per capita and governance was included. This was insignificant, leaving other estimates in the model largely unaffected. The results are available on request.

${ }^{13}$ Countries' colonial history is another important dimension of institutional heritage. However, including indicators of both legal origins and colonial history as controls is problematic, given the large degree of overlap between the two; this affects the precision of the estimates significantly. Controlling for colonial history dummies instead of legal origins produces similar results (available on request): the estimated coefficients on oil rents per capita remain negative and significant.
} 
moreover the size of the coefficient on oil rents per capita is larger. It is interesting to note that in this and subsequent models, the estimated negative coefficient on Islam is significant.

Finally, in column (5) we introduce selected characteristics related to countries' location something clearly relevant to oil production as well as having implications for women's outcomes. Latitude is one such feature which has been linked to countries' Western European influence and quality of their institutions (Hall and Jones, 1999) as well as directly capturing important geographic differences across countries (Rodrik et al., 2004). We additionally consider the effect of traditional practices of plough agriculture which have apparently influenced the evolution of gender norms (Alesina et al., 2013). This specification also includes dummies for continents. As expected, latitude is positively associated with female labour force participation while the effect of plough is negative, consistent with findings by Alesina et al. (2013); the coefficients on these variables are statistically insignificant, however. The negative significant coefficient on oil persists.

[Table 3 about here.]

Instrumental variable estimates. To estimate the causal effect of oil production on women's representation, we need an instrument for oil production. Such instrument must be important in accounting for variations in oil production but have no direct effect on women's representation. We exploit the variations in oil endowments as an instrument. Since the formation and accumulation of oil are geologically determined, variation in initial oil endowments provides exogenous variation in oil production. This identification approach follows the strategy and data used by Cotet and Tsui (2013b). The source uses estimates of total oil initially in place produced by geologists using statistical techniques involving size distributions and geological habitats (see Cotet and Tsui (2013b) for details on the construction of this variable).

Table 4 presents the results of this analysis using female labour force participation as the dependent variable. For comparability, in columns (1) and (2) we report the OLS results first. These come in two sets. First, in column (1), we reproduce the baseline results with the baseline set of controls from Ross (2008). The dataset that can be utilised in the 2SLS estimation is smaller than the original dataset used by Ross (2008) due to missing data on oil endowments exploited for identification. We therefore run a second set of OLS regressions, reported in columns (2), on the sample that is identical to that used in the 2SLS regression. The OLS estimates on oil rents per capita are similar in these two samples. 
Before proceeding with 2SLS estimations, we explore whether there is evidence that oil endowments is indeed a valid instrument in our context. First, the validity of our identification strategy would be threatened if oil endowments affect female labour force participation directly or through mechanisms other than oil rents per capita. Overidentification tests are commonly used as a device to establish the exogeneity of instruments. However, such tests rely on finding additional instruments, of which at least one needs to be truly exogenous; as in most practical contexts, this has proved to be an infeasible task here too. As an informal way of testing the exogeneity of our instrument, in column (3) of Table 4, we report the results of a regression of oil endowments per capita on female labour force participation which excludes oil rents per capita as a regressor. The coefficient on oil endowments per capita is negative and significant, however it turns insignificant once oil rents per capita is controlled for in column (4). This provides indication that the effect of our instrument on the dependent variable is likely to operate through its effect on the endogenous variable.

The second assumption behind our identification strategy is that oil endowments are a significant determinant of oil production. In column (5) of Table 4 we report the results of the first stage regression of oil rents per capita on our instrument, oil endowments per capita, and other controls. Reassuringly, the estimate on oil endowments per capita is highly significant (and positive) in the first stage. The second stage results are reported in column (6). These confirm the negative significant effect of oil rents per capita on female labour force participation suggesting that not only the findings reported by Ross (2008) can be given a causal interpretation, but that the negative effect of oil is potentially larger than the original paper suggests.

[Table 4 about here.]

As a test of robustness of the 2SLS estimates, in Table 5 we report the results which are based on the extended list of controls. Some of these, particularly those capturing the countries' location such as latitude and continent, are potentially useful for further mitigating the concerns around the endogeneity of our instrument. The drawback here, however, is that the sample size we work with is significantly smaller. Nevertheless, the corresponding 2SLS estimates confirm the negative significant effect of oil rents per capita on female labour force participation.

[Table 5 about here.] 
In addition to considering the relationship between oil production and female labour force participation, Ross (2008) studies the further implications for female representation in politics. In Table 6 we re-visit this analysis using our 2SLS approach and employing measures of female representation in parliament and cabinet as the dependent variables.

As before, we report OLS results in two sets. The first set reported in columns (1) and (5) reproduces the results based on the samples employed by Ross (2008) (these correspond to column (8) of Table 4 and column (5) of Table 5 in the original paper). ${ }^{14}$ These estimates demonstrate the negative relationships between oil rents per capita and women's representation in parliaments and cabinets. The second set of OLS results reported in columns (2) and (6) is based on the samples with non-missing values for oil endowments to allow for direct comparisons with 2SLS results. The OLS estimate of oil rents per capita on female parliamentary representation remains negative and significant in this sample; however in the model where ministerial seats held by women is employed as the dependent variable, the estimate on oil rents per capita, while negative in sign, is no longer significant.

The second stage results from 2SLS estimations are reported in columns (4) and (8) of Table 6. In both cases, we confirm the negative significant effect of oil rents per capita on female representation in politics. Moreover, in the model where ministerial seats held by women is used as the dependent variables, the size of the estimated coefficient is significantly larger (as well as statistically significant) compared to the corresponding OLS estimate reported in column (6). We thus confirm that the negative correlations between oil rents per capita and female representation in politics reported by Ross (2008) can be interpreted as causal.

[Table 6 about here.]

Oil and female employment by sector. A crucial assumption underlying the framework employed by Ross (2008) is that of gender-segregated labour markets: women can only work in the traded sector, and men in the nontraded sector. In resource-rich economies characterised by Dutch disease effects we should then observe a decline in the demand for female labour, he argues. Here we, first, formally establish this mechanism by employing the females employed in the industry sector as a share of total female employment as the dependent variable. ${ }^{15}$ In columns (1) and (2) of Table 7 we present the OLS and 2SLS results of regressions where this dependent variable is used. We confirm that oil rents per capita

\footnotetext{
${ }^{14}$ Different subsets of controls are employed in each of the three models following the exact specifications in Ross (2008).

${ }^{15}$ The industry sector consists of mining and quarrying, manufacturing, construction, and public utilities, in accordance with divisions 2-5 (ISIC 2) or categories C-F (ISIC 3) or categories B-F (ISIC 4) (World Bank, 2016).
} 
causes a decline in the share of women employed in the industry sector - a finding that is consistent with Ross's framework.

Ross's framework, however, does not allow for the possibility that women may shift to nontraded sector. Indeed, as he admits, easing this assumption would make the effects of oil production ambiguous: if more female jobs are lost in the traded sector than are gained in the nontraded sector, the demand for female workers will still drop; if more jobs are gained in the nontraded sector, the demand for female workers may increase (p. 110). To explore whether women indeed may shift to nontraded sector, we explore the effect of oil rents per capita on female employees in the services sector as a share of total female employment. ${ }^{16}$ In both OLS (column (3)) and 2SLS (column (4)) results, we confirm that oil production increases women's employment in the services sector. Thus the overall negative effect of oil production may be because of more jobs lost in the industry sector than gained in the services sector. These findings therefore suggest that with expansion of the services sector the negative oil effect documented by Ross (2008) may be potentially reversed. ${ }^{17}$

Finally, building on the discussion in the previous subsection, we further explore the possibility that women may tend to work more in the informal sector in oil-dependent economies. To do this, we consider the share of female family workers in total female employment as a dependent variable (source: World Bank (2016)). Consistent with the results of the earlier exercise, the estimates on oil rents per capita in these regressions are insignificant. $^{18}$

[Table 7 about here.]

Social consequences of oil production. By reducing female labour force participation, oil production incurs potentially significant social costs. Ross (2008) argues that the failure of women to join the nonagricultural labor force 'leads to higher fertility rates', among other things (p. 107). This conjecture is consistent with studies showing that gender inequalities in the labour market may have a range of social consequences, high fertility being among

\footnotetext{
${ }^{16}$ The services sector consists of wholesale and retail trade and restaurants and hotels; transport, storage, and communications; financing, insurance, real estate, and business services; and community, social, and personal services, in accordance with divisions 6-9 (ISIC 2) or categories G-Q (ISIC 3) or categories G-U (ISIC 4) (World Bank, 2016).

${ }^{17}$ One promising way to gain more insight into this issue is to formally test whether the nature of the relationship between oil production and women's representation varies with the overall size of the services sector by including its interaction with oil rents per capita in the model. Doing this is a largely infeasible task at this stage due to lack of data to capture the size of the services sector across a large number of countries; this is a worthwhile task for future research subject to more data availability.

${ }^{18}$ Similar results were obtained when the share of female vulnerable employment in total female employment was employed as the dependent variable (sourced from World Bank (2016)). The results are available on request.
} 
these (e.g., Do et al., 2016). However no evidence on this claim is provided by Ross (2008). Here we undertake to empirically assess this claim: we study the effect of oil production on the patterns of fertility and marriage age across countries (both variables come from World Bank (2016)).

Table 8 summarises the results. First, we consider the effect of oil rents per capita, accounting for covariates, on fertility rates across countries. In both OLS and 2SLS regressions (reported in columns (1) and (2)) we estimate a significant positive coefficient on oil rents per capita. This formally validates the claim made by Ross (2008). Second, we consider a related outcome: women's age at first marriage. As expected, here we observe that oil production leads to a decrease in the age at which women get married.

[Table 8 about here.]

\section{CONCLUSION}

The resources sector is a significant part of many economies worldwide. But can it lead to sustainable and equitable development? The problem of gender inequality is a pressing social issue in developed and developing countries alike (e.g., Duflo, 2012; Fortin, 2015). Interestingly, gender inequality is often highly prevalent in resource-rich communities (e.g., Cassells et al., 2014; Mayes, 2014). Ross (2008) suggests that the sector may in fact contribute to gender inequality and provides correlations consistent with his suggestion. In this paper we demonstrate that oil production indeed is causally linked to gender inequality.

Furthermore, we uncover an interesting nuance in the relationship between oil and women: we show that oil production decreases women's employment in the industry sector - an evidence consistent with Dutch disease effects in an economy. However, it also leads to an increase in women's employment in the services sector. Our findings therefore suggest that with an expansion of the services sector, oil may potentially turn into a blessing for women rather than being a curse. This result throws new light on the policy implications resulting from Ross's work.

As a final step, we initiated an exploration of social consequences of oil production by considering its effect on women's age at first marriage and fertility. While Ross hypothesizes that such effects can be profound, he does not test for these. We do, and we confirm that he is right: oil production increases fertility and decreases the age at marriage. Clearly, there is much more to explore in the future. Inequalities in the labour market caused by oil production can potentially lead to other outcomes such as domestic violence (e.g., Rocca 
et al., 2009) and adverse health outcomes for women (e.g., Grown et al., 2005), among other things.

More generally, gender dimensions of the resources sector remain some of the least understood aspects of the literature on economic effects of resource wealth (Ross, 2015). Extending the scope of the resource wealth studied is an important direction of future research. Furthermore, identifying contextual and institutional factors that underlie differences in gender inequalities between resource-rich communities is another area with high potential returns to further analysis. Better understanding of distributional issues in resource-rich communities appears to be needed to inform the design of dedicated policies in such communities.

\section{REFERENCES}

Adams, R. B. and D. Ferreira (2009). Women in the boardroom and their impact on governance and performance. Journal of Financial Economics 94(2), 291 - 309.

Alesina, A., P. Giuliano, and N. Nunn (2013). On the origins of gender roles: Women and the plough. The Quarterly Journal of Economics 128(2), 469.

Alexeev, M. and R. Conrad (2009). The elusive curse of oil. The Review of Economics and Statistics 91(3), 586-598.

Amin, M. and A. Islam (2015). Does mandating nondiscrimination in hiring practices influence women's employment? Evidence using firm-level data. Feminist Economics 21(4), $28-60$.

Arezki, R. and M. Bruckner (2011). Oil rents, corruption, and state stability: Evidence from panel data regressions. European Economic Review 55(7), 955 - 963.

Austen, S. and A. Mavisakalyan (2016). Constitutions and the political agency of women: A cross-country study. Feminist Economics 22(1), 183-210.

Baland, J.-M. and P. Francois (2000). Rent-seeking and resource booms. Journal of Development Economics 61(2), 527 - 542.

Bandiera, O. and A. Natraj (2013). Does gender inequality hinder development and economic growth? Evidence and policy implications. The World Bank Research Observer 28(1), 2.

Barro, R. J. (1999). Determinants of democracy. Journal of Political Economy 107(S6), S158S183.

Bertoli, S. and F. Marchetta (2015). Bringing it all back home return migration and fertility choices. World Development 65, $27-40$.

Bhattacharyya, S. and R. Hodler (2010). Natural resources, democracy and corruption. European Economic Review 54(4), 608 - 621. 
Burke, P. J. and G. Dundas (2015). Female labor force participation and household dependence on biomass energy: Evidence from national longitudinal data. World Development $67,424-437$.

Capezio, A. and A. Mavisakalyan (2016). Women in the boardroom and fraud: Evidence from Australia. Australian Journal of Management 41(4), 719-734.

Caraway, T. L. (2009). Comparative political economy, gender, and labor markets. Politics $\mathcal{E}$ Gender 5(4), 568-575.

Cassells, R., A. M. Dockery, A. Duncan, G. Gao, K. Leong, and A. Mavisakalyan (2014). Workforce and Skills: Western Australian labour markets in transition. Bankwest Curtin Economics Centre, Curtin University, Bentley, Western Australia.

Cavalcanti, T. and J. Tavares (2016). The output cost of gender discrimination: A modelbased macroeconomics estimate. The Economic Journal 126(590), 109-134.

Charrad, M. M. (2009, 12). Kinship, Islam, or oil: Culprits of gender inequality? Politics $\mathcal{E}$ Gender 5(4), 546-553.

Chattopadhyay, R. and E. Duflo (2004). Women as policy makers: Evidence from a randomized policy experiment in India. Econometrica 72(5), 1409-1443.

Collier, P. and A. Hoeffler (2009). Testing the neocon agenda: Democracy in resource-rich societies. European Economic Review 53(3), 293 - 308.

Corden, W. M. (1984). Booming sector and Dutch disease economics: Survey and consolidation. Oxford Economic Papers 36(3), 359-380.

Corden, W. M. and J. P. Neary (1982). Booming sector and de-industrialisation in a small open economy. The Economic Journal 92(368), 825-848.

Cotet, A. M. and K. K. Tsui (2013a). Oil and conflict: What does the cross country evidence really show? American Economic Journal: Macroeconomics 5(1), 49-80.

Cotet, A. M. and K. K. Tsui (2013b). Oil, growth, and health: What does the cross-country evidence really show? The Scandinavian Journal of Economics 115(4), 1107-1137.

de Soysa, I. and K. C. Vadlamannati (2011). Does being bound together suffocate, or liberate? The effects of economic, social, and political globalization on human rights, 1981-2005. Kyklos 64(1), 20-53.

Do, Q.-T., A. A. Levchenko, and C. Raddatz (2016). Comparative advantage, international trade, and fertility. Journal of Development Economics 119, 48 - 66.

Duflo, E. (2012). Women empowerment and economic development. Journal of Economic Literature 50(4), 1051-1079. 
Fenske, J. (2015). African polygamy: Past and present. Journal of Development Economics 117, $58-73$.

Fortin, N. M. (2015). Gender role attitudes and women's labor market participation: Optingout, aids, and the persistent appeal of housewifery. Annals of Economics and Statistics (117/118), 379-401.

Gaddis, I. and S. Klasen (2014). Economic development, structural change, and women's labor force participation:. Journal of Population Economics 27(3), 639-681.

Goldin, C. (1995). The U-shaped female labor force function in economic development and economic history. In P. Schultz (Ed.), Investment in Women's Human Capital. Chicago: University of Chicago Press.

Groh, M. and C. Rothschild (2012). Oil, Islam, women, and geography: A comment on Ross (2008). Quarterly Journal of Political Science 7(1), 69-87.

Grown, C., R. G. Geeta, and R. Pande (2005). Taking action to improve women's health through gender equality and women's empowerment. The Lancet 365(9458), 541-3.

Hall, R. E. and C. I. Jones (1999). Why do some countries produce so much more output per worker than others? The Quarterly Journal of Economics 114(1), 83-116.

Hansen, C. W., P. S. Jensen, and C. V. Skovsgaard (2015). Modern gender roles and agricultural history: the neolithic inheritance. Journal of Economic Growth 20(4), 365-404.

Hodler, R. (2006). The curse of natural resources in fractionalized countries. European Economic Review 50(6), 1367 - 1386.

Inglehart, R. and P. Norris (2003). Rising tide: Gender equality and cultural change around the world. Cambridge University Press.

Isham, J., M. Woolcock, L. Pritchett, and G. Busby (2005). The varieties of resource experience: Natural resource export structures and the political economy of economic growth. The World Bank Economic Review 19(2), 141-174.

Jayasuriya, D. S. and P. J. Burke (2013). Female parliamentarians and economic growth: evidence from a large panel. Applied Economics Letters 20(3), 304-307.

Kang, A. (2009). Studying oil, Islam, and women as if political institutions mattered. Politics $\mathcal{E}$ Gender 5(4), 560-568.

Kaufmann, D., A. Kraay, and M. Mastruzzi (2010). The worldwide governance indicators: Methodology and analytical issues. World Bank Policy Research Working Paper 5430.

Klasen, S. and F. Lamanna (2009). The impact of gender inequality in education and employment on economic growth: New evidence for a panel of countries. Feminist Economics 15(3), 91-132. 
La Porta, R., F. Lopez-de Silanes, and A. Shleifer (2008). The economic consequences of legal origins. Journal of economic literature 46(2), 285-332.

Laherrere, J. (2003). Future of oil supplies. Energy Exploration E Exploitation 21(3), 227-267.

Leite, C. A. and J. Weidmann (2002). Does mother nature corrupt? Natural resources, corruption, and economic growth. In G. T. Abed and S. Gupta (Eds.), Governance, corruption, and economic performance. Washington, DC: International Monetary Fund.

Mavisakalyan, A. (2014). Women in cabinet and public health spending: Evidence across countries. Economics of Governance 15(3), 281-304.

Mavisakalyan, A. (2015). Gender in language and gender in employment. Oxford Development Studies 43(4), 403-424.

Mayes, R. (2014). Gendered dimensions of resource extraction: The place of women. In M. Brueckner, A. Durey, R. Mayes, and C. Pforr (Eds.), Resource curse or cure? On the sustainability of development in Western Australia, pp. 121-133. Berlin, Heidelberg: Springer Berlin Heidelberg.

Mehlum, H., K. Moene, and R. Torvik (2006). Institutions and the resource curse. The Economic Journal 116(508), 1-20.

Norris, P. (2009). Petroleum patriarchy? A response to Ross. Politics EGender 5(4), 553-560.

Orihuela, J. C. (2013). How do 'mineral-states' learn? Path-dependence, networks, and policy change in the development of economic institutions. World Development 43, 138 148.

Parcero, O. J. and E. Papyrakis (2016). Income inequality and the oil resource curse. Resource and Energy Economics 45, 159 - 177.

Rocca, C. H., S. Rathod, T. Falle, R. P. Pande, and S. Krishnan (2009). Challenging assumptions about women's empowerment: Social and economic resources and domestic violence among young married women in urban South India. International Journal of Epidemiology 38(2), 577.

Rodrik, D., A. Subramanian, and F. Trebbi (2004). Institutions rule: The primacy of institutions over geography and integration in economic development. Journal of Economic Growth 9(2), 131 - 165.

Rørbæk, L. L. (2016). Islamic culture, oil, and women's rights revisited. Politics and Religion 9(1), 61-83.

Ross, M. and P. Mahdavi (2015). Oil and gas data, 1932-2014.

Ross, M. L. (2001). Does oil hinder democracy? World Politics 53(3), 325-361. 
Ross, M. L. (2008, 002). Oil, Islam, and women. American Political Science Review 102(1), 107-123.

Ross, M. L. (2009). Does oil wealth hurt women? A reply to Caraway, Charrad, Kang, and Norris. Politics \& Gender 5(4), 575-582.

Ross, M. L. (2010). Replication data for: Oil, Islam, and women.

Ross, M. L. (2012). What's so special about the Arabian peninsula? A reply to Groh and Rothschild. Quarterly Journal of Political Science 7(1), 89-103.

Ross, M. L. (2015). What have we learned about the resource curse? Annual Review of Political Science 18(1), 239-259.

Sachs, J. D. and A. M. Warner (1999). The big push, natural resource booms and growth. Journal of Development Economics 59(1), 43 - 76.

Sachs, J. D. and A. M. Warner (2001). The curse of natural resources. European Economic Review 45(46), 827 - 838. 15th Annual Congress of the European Economic Association.

Sala-i Martin, X. and A. Subramanian (2013). Addressing the natural resource curse: An illustration from Nigeria? Journal of African Economies 22(4), 570-615.

Schneider, F. (2002). Size and measurement of the informal economy in 100 countries around the world. Unpublished manuscript.

Sharabi, H. (1992). Neopatriarchy: A theory of distorted change in Arab society. Oxford University Press.

Tam, H. (2011). U-shaped female labor participation with economic development: Some panel data evidence. Economics Letters 110(2), 140 - 142.

Tarverdi, Y. (2016, Sep). Aspects of governance and CO2 emissions: A non-linear panel data analysis. Environmental and Resource Economics.

Tarverdi, Y. and A. Rammohan (2017). On the role of governance and health aid on child mortality: A cross-country analysis. Applied Economics 49(9), 845-859.

Tsui, K. K. (2011). More oil, less democracy: Evidence from worldwide crude oil discoveries. The Economic Journal 121(551), 89-115.

van der Ploeg, F. (2011). Natural resources: Curse or blessing? Journal of Economic Literature 49(2), 366-420.

Wehner, J. and P. de Renzio (2013). Citizens, legislators, and executive disclosure: The political determinants of fiscal transparency. World Development 41, 96 - 108.

Wick, K. and E. Bulte (2009). The curse of natural resources. Annual Review of Resource Economics 1(1), 139-156.

World Bank (2016). World Development Indicators database. Computer file. 


\section{LIST OF TABLES}

1 Parsimonious and baseline OLS regressions $\quad 21$

2 OLS regressions with alternative measures of oil wealth 22

3 OLS regressions with additional controls 23

4 Addressing endogeneity of oil production: OLS and 2SLS regressions 24

5 Addressing endogeneity of oil production: OLS and 2SLS regressions with 25

6 Oil and female political representation: OLS and 2SLS regressions 26

7 Oil and female employment by sector: OLS and 2SLS regressions 27

8 Social consequences of oil production: OLS and 2SLS regressions 28 
Table 1: Parsimonious and baseline OLS regressions

\begin{tabular}{lccccc}
\hline \hline & \multicolumn{3}{c}{ Female LFP } & & \\
\hline & $(1)$ & $(2)$ & $(3)$ & $(4)$ & $(5)$ \\
\hline Oil rents per capita $^{\dagger}$ & $-0.418^{* * *}$ & $-0.327^{* * *}$ & $-0.198^{* * *}$ & $-0.152^{* * *}$ & $-0.210^{* * *}$ \\
& $(0.079)$ & $(0.071)$ & $(0.048)$ & $(0.052)$ & $(0.055)$ \\
Income (log) & & & & & $-1.864^{* *}$ \\
& & & & & $(0.878)$ \\
Income squared (log) & & & & & $2.122^{* *}$ \\
& & & & $-0.158^{*}$ & $-0.350^{* *}$ \\
Working age & & & & $(0.084)$ & $(0.142)$ \\
& & & $-0.405^{* * *}$ & $-0.369^{* * *}$ & $-0.326^{* * *}$ \\
Middle East & & & $(0.099)$ & $(0.108)$ & $(0.117)$ \\
& & & 0.076 & $0.135^{*}$ & $0.286^{* * *}$ \\
Communist & & & $(0.065)$ & $(0.080)$ & $(0.104)$ \\
& & $-0.303^{* * *}$ & -0.093 & -0.158 & -0.139 \\
Islam & & $(0.087)$ & $(0.106)$ & $(0.122)$ & $(0.116)$ \\
& 0.001 & -0.003 & -0.008 & -0.014 & -0.012 \\
Constant & $(0.070)$ & $(0.067)$ & $(0.063)$ & $(0.063)$ & $(0.060)$ \\
\hline Observations & 169 & 169 & 169 & 167 & 167 \\
R-squared & 0.175 & 0.258 & 0.354 & 0.372 & 0.427 \\
\hline \hline
\end{tabular}

Note: All variables are standardized. Robust standard errors in parentheses. ${ }^{* * *} p<0.01{ }^{* *} p<0.05,{ }^{*} p<0.1$. LFP refers to non-agricultural labour force participation. ${ }^{\dagger}$ Oil refers to both oil and gas. 
Table 2: OLS regressions with alternative measures of oil wealth

\begin{tabular}{|c|c|c|c|c|c|c|}
\hline \multicolumn{4}{|c|}{ Female LFP } & \multirow[b]{2}{*}{ (4) } & \multirow[b]{2}{*}{ (5) } & \multirow[b]{2}{*}{ (6) } \\
\hline & $(1)$ & $(2)$ & (3) & & & \\
\hline Oil rents per capita $^{\dagger}$ & $\begin{array}{c}-0.210^{* * *} \\
(0.055)\end{array}$ & & & & & \\
\hline Net oil export per capita $^{\dagger}$ & & $\begin{array}{c}-0.129^{* *} \\
(0.065)\end{array}$ & & & & \\
\hline Oil reserves per capita $^{\dagger}$ & & & $\begin{array}{c}-0.139^{* *} \\
(0.055)\end{array}$ & & & \\
\hline Oil rents in $\mathrm{GDP}^{+}$ & & & & $\begin{array}{l}-0.004 \\
(0.047)\end{array}$ & & \\
\hline Net oil export in $\mathrm{GDP}^{\dagger}$ & & & & & $\begin{array}{l}-0.005 \\
(0.061)\end{array}$ & \\
\hline Oil reserves in $\mathrm{GDP}^{\dagger}$ & & & & & & $\begin{array}{c}-0.003 \\
(0.050)\end{array}$ \\
\hline Income (log) & $\begin{array}{c}-1.864^{* *} \\
(0.878)\end{array}$ & $\begin{array}{l}-1.671^{*} \\
(0.874)\end{array}$ & $\begin{array}{l}-1.450 \\
(0.939)\end{array}$ & $\begin{array}{l}-1.636^{*} \\
(0.894)\end{array}$ & $\begin{array}{l}-1.627^{*} \\
(0.913)\end{array}$ & $\begin{array}{l}-1.584^{*} \\
(0.955)\end{array}$ \\
\hline Income squared (log) & $\begin{array}{l}2.122^{* *} \\
(0.824)\end{array}$ & $\begin{array}{l}1.939^{* *} \\
(0.824)\end{array}$ & $\begin{array}{l}1.710^{*} \\
(0.882)\end{array}$ & $\begin{array}{l}1.898^{* *} \\
(0.839)\end{array}$ & $\begin{array}{l}1.893^{* *} \\
(0.843)\end{array}$ & $\begin{array}{l}1.829 * * \\
(0.891)\end{array}$ \\
\hline Working age & $\begin{array}{c}-0.350^{* *} \\
(0.142)\end{array}$ & $\begin{array}{c}-0.401^{* * *} \\
(0.142)\end{array}$ & $\begin{array}{c}-0.418^{* * * *} \\
(0.144)\end{array}$ & $\begin{array}{c}-0.405^{* * *} \\
(0.154)\end{array}$ & $\begin{array}{c}-0.410^{* *} \\
(0.164)\end{array}$ & $\begin{array}{c}-0.400^{* * *} \\
(0.152)\end{array}$ \\
\hline Middle East & $\begin{array}{c}-0.326^{* * *} \\
(0.117)\end{array}$ & $\begin{array}{c}-0.379^{* * *} \\
(0.120)\end{array}$ & $\begin{array}{c}-0.344^{* * *} \\
(0.125)\end{array}$ & $\begin{array}{c}-0.371^{* * *} \\
(0.127)\end{array}$ & $\begin{array}{c}-0.376^{* * *} \\
(0.128)\end{array}$ & $\begin{array}{c}-0.367^{* * *} \\
(0.129)\end{array}$ \\
\hline Communist & $\begin{array}{c}0.286^{* * *} \\
(0.104)\end{array}$ & $\begin{array}{c}0.290^{* * *} \\
(0.105)\end{array}$ & $\begin{array}{c}0.300^{* * *} \\
(0.108)\end{array}$ & $\begin{array}{c}0.304^{* * *} \\
(0.115)\end{array}$ & $\begin{array}{c}0.296^{* * *} \\
(0.112)\end{array}$ & $\begin{array}{c}0.293^{* * *} \\
(0.112)\end{array}$ \\
\hline Islam & $\begin{array}{l}-0.139 \\
(0.116)\end{array}$ & $\begin{array}{l}-0.146 \\
(0.117)\end{array}$ & $\begin{array}{l}-0.164 \\
(0.115)\end{array}$ & $\begin{array}{c}-0.178 \\
(0.124)\end{array}$ & $\begin{array}{l}-0.172 \\
(0.124)\end{array}$ & $\begin{array}{l}-0.180 \\
(0.124)\end{array}$ \\
\hline Constant & $\begin{array}{l}-0.012 \\
(0.060)\end{array}$ & $\begin{array}{l}-0.013 \\
(0.062)\end{array}$ & $\begin{array}{l}-0.023 \\
(0.063)\end{array}$ & $\begin{array}{l}-0.019 \\
(0.065)\end{array}$ & $\begin{array}{l}-0.020 \\
(0.066)\end{array}$ & $\begin{array}{l}-0.030 \\
(0.066)\end{array}$ \\
\hline Observations & 167 & 165 & 162 & 160 & 158 & 155 \\
\hline R-squared & 0.427 & 0.410 & 0.405 & 0.369 & 0.369 & 0.363 \\
\hline
\end{tabular}

Note: All variables are standardized. Robust standard errors in parentheses. ${ }^{* * *} p<0.01,{ }^{* *} p<$ $0.05,{ }^{*} p<0.1$. LFP refers to non-agricultural labour force participation. ${ }^{\dagger}$ Oil refers to both oil and gas. 
Table 3: OLS regressions with additional controls

\begin{tabular}{|c|c|c|c|c|c|}
\hline \multicolumn{6}{|c|}{ Female LFP } \\
\hline & $(1)$ & (2) & (3) & (4) & (5) \\
\hline \multirow[t]{2}{*}{ Oil rents per capita $^{+}$} & $-0.210^{* * *}$ & $-0.210^{* * *}$ & $-0.167^{* * *}$ & $-0.460^{* * *}$ & $-0.315^{*}$ \\
\hline & $(0.055)$ & $(0.064)$ & $(0.061)$ & $(0.169)$ & (0.165) \\
\hline \multirow[t]{2}{*}{ Income (log) } & $-1.864^{* *}$ & $-2.808^{* * *}$ & $-2.340^{* * *}$ & $-3.083^{* * *}$ & -1.864 \\
\hline & $(0.878)$ & $(0.664)$ & $(0.660)$ & $(1.115)$ & $(1.299)$ \\
\hline \multirow[t]{2}{*}{ Income squared (log) } & $2.122^{* *}$ & $2.937^{* * *}$ & $2.107^{* * *}$ & $3.055^{* * *}$ & 1.906 \\
\hline & $(0.824)$ & $(0.638)$ & $(0.658)$ & (1.033) & (1.231) \\
\hline \multirow[t]{2}{*}{ Working age } & $-0.350^{* *}$ & $-0.276^{*}$ & $-0.367^{* *}$ & $-0.378^{* *}$ & -0.229 \\
\hline & $(0.142)$ & $(0.147)$ & $(0.151)$ & $(0.186)$ & $(0.181)$ \\
\hline \multirow[t]{2}{*}{ Middle East } & $-0.326^{* * *}$ & $-0.254^{*}$ & -0.166 & 0.095 & -0.048 \\
\hline & $(0.117)$ & $(0.142)$ & $(0.146)$ & $(0.180)$ & (0.148) \\
\hline \multirow[t]{2}{*}{ Communist } & $0.286^{* * *}$ & $0.251^{*}$ & 0.161 & $0.390^{* * *}$ & $0.393^{* * *}$ \\
\hline & (0.104) & (0.148) & (0.190) & $(0.143)$ & $(0.134)$ \\
\hline \multirow[t]{2}{*}{ Islam } & -0.139 & -0.204 & -0.199 & $-0.461^{* * *}$ & $-0.507^{* * *}$ \\
\hline & $(0.116)$ & $(0.151)$ & $(0.145)$ & $(0.173)$ & $(0.144)$ \\
\hline \multirow[t]{2}{*}{ Average years of schooling $(+15)$} & & 0.060 & 0.119 & -0.060 & 0.009 \\
\hline & & $(0.166)$ & $(0.182)$ & $(0.186)$ & $(0.143)$ \\
\hline \multirow[t]{2}{*}{ Governance } & & & $0.387^{* * *}$ & $0.404^{* *}$ & $0.305^{* *}$ \\
\hline & & & $(0.130)$ & $(0.175)$ & $(0.143)$ \\
\hline \multirow[t]{2}{*}{ Size of informal economy } & & & & 0.086 & -0.033 \\
\hline & & & & $(0.084)$ & $(0.087)$ \\
\hline \multirow[t]{2}{*}{ Latitude } & & & & & $0.286^{* *}$ \\
\hline & & & & & $(0.132)$ \\
\hline \multirow[t]{2}{*}{ Plough } & & & & & 0.006 \\
\hline & & & & & $(0.156)$ \\
\hline \multirow[t]{2}{*}{ Constant } & -0.012 & -0.041 & -0.056 & -0.141 & -0.063 \\
\hline & $(0.060)$ & $(0.069)$ & $(0.066)$ & $(0.086)$ & $(0.068)$ \\
\hline Legal origins & No & No & Yes & Yes & Yes \\
\hline Continents & No & No & No & No & Yes \\
\hline Observations & 167 & 137 & 135 & 95 & 94 \\
\hline R-squared & 0.427 & 0.498 & 0.553 & 0.605 & 0.745 \\
\hline
\end{tabular}

Note: All variables are standardized. Robust standard errors in parentheses. ${ }^{* * *} p<$ $0.01{ }^{* *} p<0.05,{ }^{*} p<0.1$. LFP refers to non-agricultural labour force participation. ${ }^{\dagger}$ Oil refers to both oil and gas. 
Table 4: Addressing endogeneity of oil production: OLS and 2SLS regressions

\begin{tabular}{|c|c|c|c|c|c|c|}
\hline & (1) & (2) & (3) & (4) & (5) & (6) \\
\hline & \multicolumn{4}{|c|}{ OLS } & \multicolumn{2}{|c|}{ 2SLS } \\
\hline & & & & & $1^{\text {st }}$ Stage & $2^{\text {nd }}$ Stage \\
\hline Oil rents per capita $^{\dagger}$ & $\begin{array}{c}-0.210^{* * *} \\
(0.055)\end{array}$ & $\begin{array}{c}-0.231^{* * *} \\
(0.067)\end{array}$ & & $\begin{array}{c}-0.183^{* * *} \\
(0.061)\end{array}$ & & $\begin{array}{c}-0.271^{* * *} \\
(0.076)\end{array}$ \\
\hline Oil endowments per capita & & & $\begin{array}{c}-0.211^{* *} \\
(0.085)\end{array}$ & $\begin{array}{l}-0.069 \\
(0.070)\end{array}$ & $\begin{array}{c}0.778^{* * *} \\
(0.185)\end{array}$ & \\
\hline Income(log) & $\begin{array}{c}-1.864^{* *} \\
(0.878)\end{array}$ & $\begin{array}{c}-2.801^{* * *} \\
(0.699)\end{array}$ & $\begin{array}{c}-2.649^{* * *} \\
(0.699)\end{array}$ & $\begin{array}{c}-2.819^{* * *} \\
(0.703)\end{array}$ & $\begin{array}{l}-0.933 \\
(0.708)\end{array}$ & $\begin{array}{c}-2.902^{* * *} \\
(0.691)\end{array}$ \\
\hline Income squared $(\log )$ & $\begin{array}{l}2.122^{* *} \\
(0.824)\end{array}$ & $\begin{array}{c}3.043^{* * *} \\
(0.702)\end{array}$ & $\begin{array}{c}2.892^{* * * *} \\
(0.704)\end{array}$ & $\begin{array}{c}3.063^{* * *} \\
(0.706)\end{array}$ & $\begin{array}{c}0.932 \\
(0.644)\end{array}$ & $\begin{array}{c}3.145^{* * *} \\
(0.691)\end{array}$ \\
\hline Working age & $\begin{array}{c}-0.350^{* *} \\
(0.142)\end{array}$ & $\begin{array}{c}-0.366^{* *} \\
(0.155)\end{array}$ & $\begin{array}{c}-0.385^{* *} \\
(0.155)\end{array}$ & $\begin{array}{c}-0.364^{* *} \\
(0.156)\end{array}$ & $\begin{array}{c}0.119 \\
(0.142)\end{array}$ & $\begin{array}{c}-0.353^{* *} \\
(0.152)\end{array}$ \\
\hline Middle East & $\begin{array}{c}-0.326^{* * *} \\
(0.117)\end{array}$ & $\begin{array}{c}-0.360^{* * *} \\
(0.136)\end{array}$ & $\begin{array}{c}-0.388^{* * *} \\
(0.137)\end{array}$ & $\begin{array}{c}-0.355^{* *} \\
(0.138)\end{array}$ & $\begin{array}{c}0.181 \\
(0.103)\end{array}$ & $\begin{array}{c}-0.339^{* *} \\
(0.136)\end{array}$ \\
\hline Communist & $\begin{array}{c}0.286^{* * *} \\
(0.104)\end{array}$ & $\begin{array}{l}0.297^{* *} \\
(0.136)\end{array}$ & $\begin{array}{l}0.301^{* *} \\
(0.136)\end{array}$ & $\begin{array}{l}0.298^{* *} \\
(0.136)\end{array}$ & $\begin{array}{l}-0.019 \\
(0.047)\end{array}$ & $\begin{array}{l}0.296^{* *} \\
(0.131)\end{array}$ \\
\hline Islam & $\begin{array}{c}-0.139 \\
(0.116)\end{array}$ & $\begin{array}{l}-0.100 \\
(0.126)\end{array}$ & $\begin{array}{l}-0.102 \\
(0.125)\end{array}$ & $\begin{array}{l}-0.098 \\
(0.126)\end{array}$ & $\begin{array}{c}0.018 \\
(0.022)\end{array}$ & $\begin{array}{l}-0.097 \\
(0.122)\end{array}$ \\
\hline Constant & $\begin{array}{l}-0.012 \\
(0.060)\end{array}$ & $\begin{array}{c}0.000 \\
(0.064)\end{array}$ & $\begin{array}{l}-0.011 \\
(0.064)\end{array}$ & $\begin{array}{l}-0.002 \\
(0.064)\end{array}$ & $\begin{array}{c}0.046 \\
(0.052)\end{array}$ & $\begin{array}{c}0.002 \\
(0.062)\end{array}$ \\
\hline Observations & 167 & 119 & 119 & 119 & 119 & 119 \\
\hline R-squared & 0.427 & 0.562 & 0.553 & 0.564 & & 0.561 \\
\hline
\end{tabular}

Note: All variables are standardized. Robust standard errors in parentheses. ${ }^{* * *} p<0.01,{ }^{* *} p<$ $0.05,{ }^{*} p<0.1{ }^{\dagger}$ Oil refers to both oil and gas. 
Table 5: Addressing endogeneity of oil production: OLS and 2SLS regressions with additional controls

\begin{tabular}{|c|c|c|c|}
\hline & (1) & (2) & (3) \\
\hline & OLS & \multicolumn{2}{|c|}{ 2SLS } \\
\hline & & $1^{\text {st }}$ Stage & $2^{\text {nd }}$ Stage \\
\hline Oil rents per capita $^{+}$ & $\begin{array}{l}-0.315^{*} \\
(0.165)\end{array}$ & & $\begin{array}{c}-0.502^{* * *} \\
(0.136)\end{array}$ \\
\hline Oil endowments per capita & & $\begin{array}{c}0.861^{* * *} \\
(0.050)\end{array}$ & \\
\hline Income $(\log )$ & $\begin{array}{l}-1.864 \\
(1.299)\end{array}$ & $\begin{array}{l}-0.065 \\
(0.146)\end{array}$ & $\begin{array}{c}-2.740^{* * *} \\
(1.097)\end{array}$ \\
\hline Income squared(log) & $\begin{array}{c}1.906 \\
(1.231)\end{array}$ & $\begin{array}{c}0.157 \\
(0.171)\end{array}$ & $\begin{array}{c}3.096^{* * *} \\
(1.027)\end{array}$ \\
\hline Working age & $\begin{array}{l}-0.229 \\
(0.181)\end{array}$ & $\begin{array}{l}-0.010 \\
(0.027)\end{array}$ & $\begin{array}{l}-0.233 \\
(0.193)\end{array}$ \\
\hline Middle East & $\begin{array}{c}-0.048 \\
(0.148)\end{array}$ & $\begin{array}{c}0.045 \\
(0.029)\end{array}$ & $\begin{array}{l}-0.068 \\
(0.154)\end{array}$ \\
\hline Communist & $\begin{array}{c}0.393^{* * *} \\
(0.134)\end{array}$ & $\begin{array}{c}0.043 \\
(0.038)\end{array}$ & $\begin{array}{c}0.558^{* * *} \\
(0.122)\end{array}$ \\
\hline Islam & $\begin{array}{c}-0.507^{* * *} \\
(0.144)\end{array}$ & $\begin{array}{c}0.011 \\
(0.017)\end{array}$ & $\begin{array}{c}-0.483^{* * *} \\
(0.136)\end{array}$ \\
\hline Average years of schooling $(+15)$ & $\begin{array}{c}0.009 \\
(0.143)\end{array}$ & $\begin{array}{l}-0.028 \\
(0.024)\end{array}$ & $\begin{array}{c}-0.085 \\
(0.154)\end{array}$ \\
\hline Governance & $\begin{array}{l}0.305^{* *} \\
(0.143)\end{array}$ & $\begin{array}{l}-0.043 \\
(0.026)\end{array}$ & $\begin{array}{l}0.238^{*} \\
(0.127)\end{array}$ \\
\hline Size of informal economy & $\begin{array}{l}-0.033 \\
(0.087)\end{array}$ & $\begin{array}{l}-0.014 \\
(0.014)\end{array}$ & $\begin{array}{c}0.063 \\
(0.080)\end{array}$ \\
\hline Latitude & $\begin{array}{l}0.286^{* *} \\
(0.132)\end{array}$ & $\begin{array}{c}0.019 \\
(0.030)\end{array}$ & $\begin{array}{l}0.279^{* *} \\
(0.120)\end{array}$ \\
\hline Plough & $\begin{array}{c}0.006 \\
(0.156)\end{array}$ & $\begin{array}{l}-0.041 \\
(0.052)\end{array}$ & $\begin{array}{l}-0.126 \\
(0.125)\end{array}$ \\
\hline Constant & $\begin{array}{l}-0.063 \\
(0.068)\end{array}$ & $\begin{array}{c}0.004 \\
(0.014)\end{array}$ & $\begin{array}{l}-0.021 \\
(0.058)\end{array}$ \\
\hline Legal origins & Yes & Yes & Yes \\
\hline Continents & Yes & Yes & Yes \\
\hline Observations & 94 & 71 & 71 \\
\hline R-squared & 0.745 & & 0.792 \\
\hline
\end{tabular}

Note: All variables are standardized. Robust standard errors in parentheses. ${ }^{* * *} p<0.01,{ }^{* *} p<0.05,{ }^{*} p<0.1$. ${ }^{\dagger}$ Oil refers to both oil and gas. 


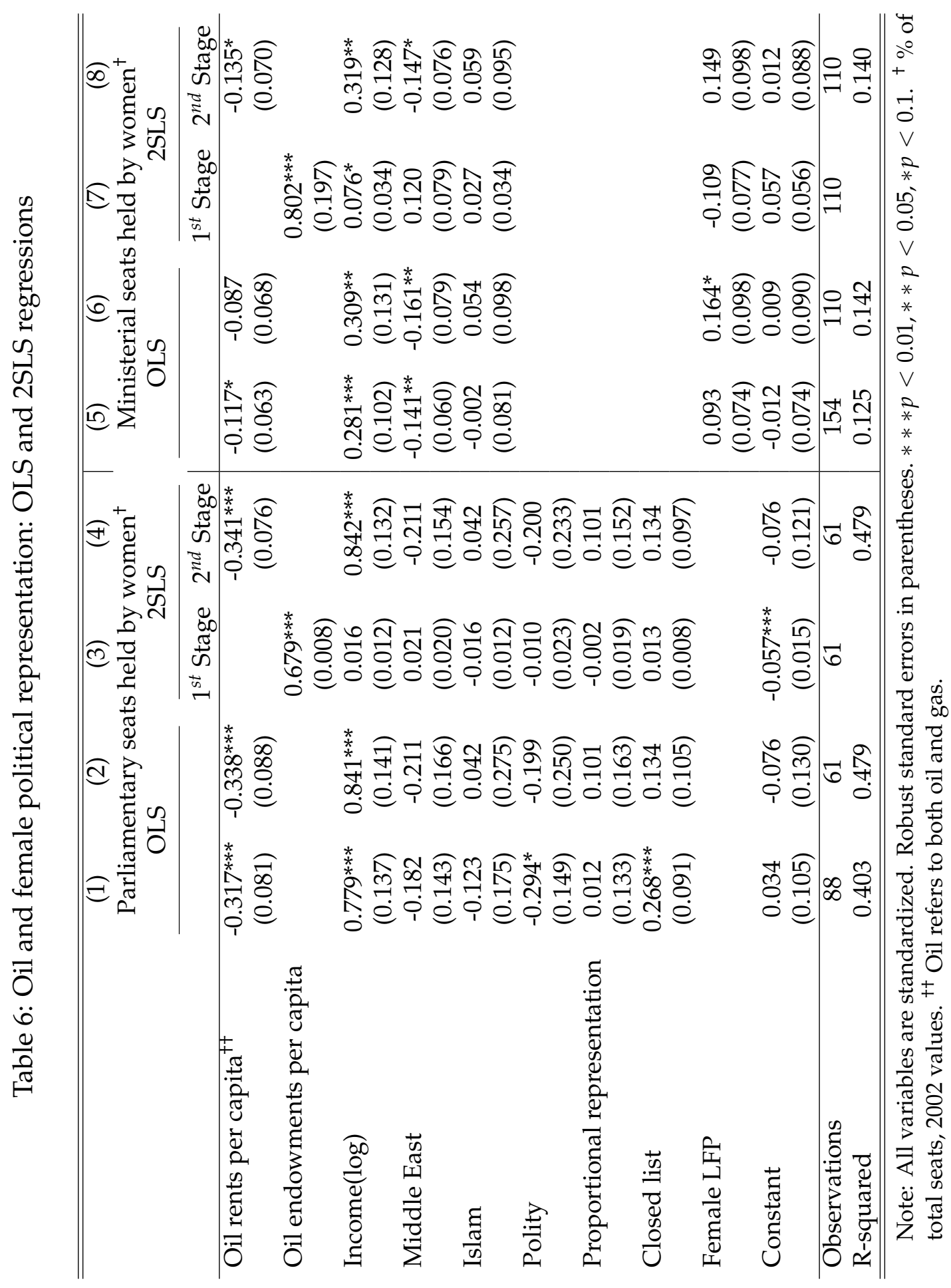


Table 7: Oil and female employment by sector: OLS and 2SLS regressions

\begin{tabular}{|c|c|c|c|c|c|c|}
\hline & \multirow{2}{*}{\multicolumn{2}{|c|}{$\begin{array}{cc}(1) & (2) \\
\text { Female employees, industry }\end{array}$}} & \multirow{2}{*}{\multicolumn{2}{|c|}{$\begin{array}{c}(3) \\
\text { Female employees, services }\end{array}$}} & \multirow{2}{*}{\multicolumn{2}{|c|}{$\begin{array}{c}(5) \quad(6) \\
\text { Female family workers }\end{array}$}} \\
\hline & & & & & & \\
\hline & OLS & 2SLS & OLS & 2SLS & OLS & 2SLS \\
\hline Oil rents per capita $^{t+}$ & $\begin{array}{c}-0.310^{* * *} \\
(0.077)\end{array}$ & $\begin{array}{c}-0.343^{* * *} \\
(0.095)\end{array}$ & $\begin{array}{c}0.172^{* * *} \\
(0.045)\end{array}$ & $\begin{array}{c}0.188^{* *} \\
(0.0831)\end{array}$ & $\begin{array}{l}-0.263 \\
(0.158)\end{array}$ & $\begin{array}{c}-0.511 \\
(0.330)\end{array}$ \\
\hline Income $(\log )$ & $\begin{array}{c}4.692^{* * *} \\
(0.980)\end{array}$ & $\begin{array}{c}4.107^{* * *} \\
(0.838)\end{array}$ & $\begin{array}{c}4.401^{* * *} \\
(0.793)\end{array}$ & $\begin{array}{c}5.153^{* * *} \\
(0.896)\end{array}$ & $\begin{array}{c}-3.411^{* * *} \\
(1.025)\end{array}$ & $\begin{array}{l}-2.545^{*} \\
(1.430)\end{array}$ \\
\hline Income squared(log) & $\begin{array}{c}-4.537^{* * *} \\
(0.888)\end{array}$ & $\begin{array}{c}-4.237^{* * *} \\
(0.812)\end{array}$ & $\begin{array}{c}-3.387^{* * *} \\
(0.725)\end{array}$ & $\begin{array}{c}-4.010^{* * *} \\
(0.781)\end{array}$ & $\begin{array}{c}2.590^{* * *} \\
(0.915)\end{array}$ & $\begin{array}{c}1.958 \\
(1.278)\end{array}$ \\
\hline Working age & $\begin{array}{c}0.543^{* * *} \\
(0.201)\end{array}$ & $\begin{array}{c}0.799^{* * *} \\
(0.176)\end{array}$ & $\begin{array}{l}-0.110 \\
(0.163)\end{array}$ & $\begin{array}{l}-0.149 \\
(0.217)\end{array}$ & $\begin{array}{c}0.160 \\
(0.188)\end{array}$ & $\begin{array}{c}0.002 \\
(0.229)\end{array}$ \\
\hline Middle East & $\begin{array}{l}0.0410 \\
(0.205)\end{array}$ & $\begin{array}{c}0.206 \\
(0.186)\end{array}$ & $\begin{array}{c}0.133 \\
(0.091)\end{array}$ & $\begin{array}{c}0.174 \\
(0.145)\end{array}$ & $\begin{array}{l}-0.335 \\
(0.210)\end{array}$ & $\begin{array}{l}-0.387^{*} \\
(0.215)\end{array}$ \\
\hline Communist & $\begin{array}{l}0.0126 \\
(0.106)\end{array}$ & $\begin{array}{l}-0.139 \\
(0.102)\end{array}$ & $\begin{array}{l}0.0123 \\
(0.085)\end{array}$ & $\begin{array}{c}0.101 \\
(0.102)\end{array}$ & $\begin{array}{l}-0.163 \\
(0.126)\end{array}$ & $\begin{array}{c}0.002 \\
(0.163)\end{array}$ \\
\hline Islam & $\begin{array}{c}0.205 \\
(0.214)\end{array}$ & $\begin{array}{l}-0.089 \\
(0.156)\end{array}$ & $\begin{array}{c}-0.353^{* * *} \\
(0.118)\end{array}$ & $\begin{array}{c}-0.413^{* * *} \\
(0.158)\end{array}$ & $\begin{array}{l}0.462^{*} \\
(0.238)\end{array}$ & $\begin{array}{c}0.629^{* * *} \\
(0.236)\end{array}$ \\
\hline Constant & $\begin{array}{c}-0.272^{* * *} \\
(0.088)\end{array}$ & $\begin{array}{c}-0.320^{* * *} \\
(0.081)\end{array}$ & $\begin{array}{c}-0.620^{* * *} \\
(0.072)\end{array}$ & $\begin{array}{l}-0.704^{* * *} \\
(0.0744)\end{array}$ & $\begin{array}{c}0.367^{* * *} \\
(0.124)\end{array}$ & $\begin{array}{l}0.358^{* *} \\
(0.173)\end{array}$ \\
\hline Observations & 105 & 74 & 105 & 74 & 100 & 66 \\
\hline R-squared & 0.386 & 0.474 & 0.746 & 0.771 & 0.522 & 0.453 \\
\hline
\end{tabular}


Table 8: Social consequences of oil production: OLS and 2SLS regressions

\begin{tabular}{|c|c|c|c|c|}
\hline & 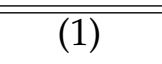 & (2) & (3) & (4) \\
\hline & \multicolumn{2}{|c|}{ Fertility rate (\%) } & \multicolumn{2}{|c|}{ Marriage age, females } \\
\hline & OLS & 2SLS & OLS & 2SLS \\
\hline Oil rents per capita $^{+}$ & $\begin{array}{c}0.160^{* * *} \\
(0.029)\end{array}$ & $\begin{array}{c}0.181^{* * *} \\
(0.035)\end{array}$ & $\begin{array}{c}-0.167^{* * *} \\
(0.046)\end{array}$ & $\begin{array}{c}-0.158^{* *} \\
(0.068)\end{array}$ \\
\hline Income (log) & $\begin{array}{c}-1.386^{* * *} \\
(0.268)\end{array}$ & $\begin{array}{c}-1.685^{* * *} \\
(0.275)\end{array}$ & $\begin{array}{l}-0.030 \\
(0.599)\end{array}$ & $\begin{array}{c}0.702 \\
(0.809)\end{array}$ \\
\hline Income squared (log) & $\begin{array}{c}1.141^{* * *} \\
(0.247)\end{array}$ & $\begin{array}{c}1.440^{* * *} \\
(0.262)\end{array}$ & $\begin{array}{c}0.723 \\
(0.575)\end{array}$ & $\begin{array}{c}0.058 \\
(0.775)\end{array}$ \\
\hline Working age & $\begin{array}{c}-0.691^{* * *} \\
(0.051)\end{array}$ & $\begin{array}{c}-0.685^{* * *} \\
(0.053)\end{array}$ & $\begin{array}{c}0.040 \\
(0.098)\end{array}$ & $\begin{array}{l}-0.028 \\
(0.104)\end{array}$ \\
\hline Middle East & $\begin{array}{l}-0.022 \\
(0.052)\end{array}$ & $\begin{array}{l}-0.084^{*} \\
(0.051)\end{array}$ & $\begin{array}{c}0.239 * * * \\
(0.074)\end{array}$ & $\begin{array}{l}0.190^{* *} \\
(0.091)\end{array}$ \\
\hline Communist & $\begin{array}{c}-0.167^{* * *} \\
(0.035)\end{array}$ & $\begin{array}{c}-0.183^{* * *} \\
(0.039)\end{array}$ & $\begin{array}{c}0.080 \\
(0.054)\end{array}$ & $\begin{array}{l}0.120^{* *} \\
(0.054)\end{array}$ \\
\hline Islam & $\begin{array}{c}0.080 \\
(0.054)\end{array}$ & $\begin{array}{c}0.168^{* * *} \\
(0.049)\end{array}$ & $\begin{array}{l}-0.101 \\
(0.062)\end{array}$ & $\begin{array}{c}-0.071 \\
(0.064)\end{array}$ \\
\hline Constant & $\begin{array}{c}0.025 \\
(0.025)\end{array}$ & $\begin{array}{c}0.028 \\
(0.026)\end{array}$ & $\begin{array}{c}-0.135^{* * *} \\
(0.048)\end{array}$ & $\begin{array}{c}-0.130^{* *} \\
(0.054)\end{array}$ \\
\hline Observations & 165 & 119 & 158 & 114 \\
\hline R-squared & 0.907 & 0.921 & 0.608 & 0.597 \\
\hline
\end{tabular}

Note: All variables are standardized. Robust standard errors in parentheses. ${ }^{* * *} p<0.01,{ }^{* *} p<0.05,{ }^{*} p<0.1 .{ }^{+}$Oil refers to both oil and gas. 